\title{
Sam Whiteside's Prairie Creek Sites in Smith County, Texas
}

Mark Walters

Heritage Research Center, Stephen F. Austin State University

Timothy K. Perttula

Heritage Research Center, Stephen F. Austin State University

Follow this and additional works at: https://scholarworks.sfasu.edu/ita

Part of the American Material Culture Commons, Archaeological Anthropology Commons, Environmental Studies Commons, Other American Studies Commons, Other Arts and Humanities Commons, Other History of Art, Architecture, and Archaeology Commons, and the United States History Commons

Tell us how this article helped you.

This Article is brought to you for free and open access by the Center for Regional Heritage Research at SFA ScholarWorks. It has been accepted for inclusion in Index of Texas Archaeology: Open Access Gray Literature from the Lone Star State by an authorized editor of SFA ScholarWorks. For more information, please contact cdsscholarworks@sfasu.edu. 


\section{Sam Whiteside's Prairie Creek Sites in Smith County, Texas}

Creative Commons License

(c) (i) (8)

This work is licensed under a Creative Commons Attribution-NonCommercial 4.0 International License 


\title{
Sam Whiteside's Prairie Creek Sites in Smith County, Texas
}

\author{
Mark Walters and Timothy K. Perttula
}

\section{INTRODUCTION}

During primarily the late 1950s Sam Whiteside investigated a slate of sites on the upper reaches of Prairie Creek in eastern Smith County, Texas (Walters 2005) (Figure 1). Archaeological investigations ranged from fairly extensive efforts at a couple of sites, including the Chapman site (41SM56) (Walters 2009), to fairly limited excavations at others based on the amount of recovered artifacts. Artifacts and notes from a number of the sites were donated by Sam Whiteside to the Texas Archeological Research Laboratory at The University of Texas at Austin. However, artifacts and notes from other Prairie Creek sites were kept by the family and after Mr. Whiteside's death were made available to the senior author. Other than the Chapman site (Walters 2009), none of the archaeological findings from other sites has been published. This article makes that information available to the archaeological community in Texas.

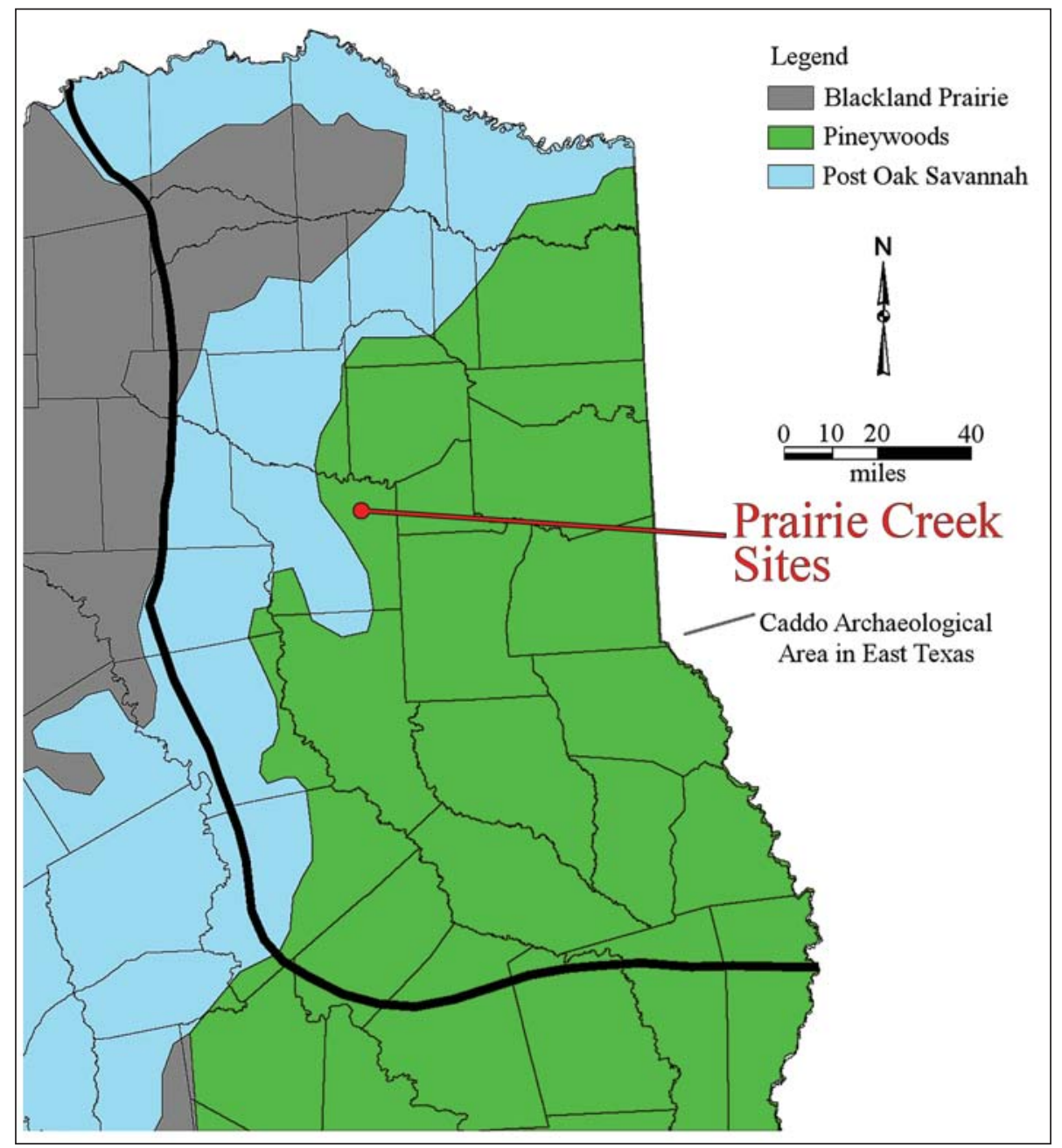

Figure 1. Location of Prairie Creek sites in East Texas. 
41SM53 ( $\mathrm{P}-4)$ is one of three sites that Sam Whiteside investigated on the Dr. Smith farm on Prairie Creek. The other sites identified as being on the Smith farm were 41SM51 (P-2) and 41SM52 (P-3). These sites were located on alluvial landforms on the north bank of Prairie Creek and were within ca. $245 \mathrm{~m}$ of each other. One burial (Burial 1) was excavated at the site by Whiteside.

There are 23 ceramic rim and body sherds in the collection from 41SM53 (Table 1). They are from vessels tempered with grog $(n=18,78$ percent) and grog and bone $(n=5,22$ percent). Most of the sherds are from vessels fired in a reducing or low oxygen environment (91 percent), and the vessels were smoothed or burnished before or after firing.

Table 1. Ceramic sherds from 41SM53.

\begin{tabular}{|c|c|c|c|c|c|c|c|}
\hline$\#$ & Sherd & Temper & $\mathrm{ST}^{*}$ & $\mathrm{FC}$ & $\begin{array}{l}\text { Th } \\
(\mathrm{mm})\end{array}$ & Decoration & Comments \\
\hline 1 & body & $\mathrm{g}$ & $\mathrm{I} / \mathrm{E} \mathrm{SM}$ & $\mathrm{F}$ & 6.1 & plain & \\
\hline 2 & body & $\mathrm{g}$ & I/E SM & B & 7.0 & plain & \\
\hline 3 & body & $\mathrm{g}$ & E SM & F & 7.1 & plain & \\
\hline 4 & body & $\mathrm{g}$ & $\mathrm{I} / \mathrm{E} \mathrm{SM}$ & $\mathrm{B}$ & 8.1 & plain & \\
\hline 5 & body & $\mathrm{g}$ & $\mathrm{I} / \mathrm{E} \mathrm{SM}$ & $\mathrm{F}$ & 7.6 & plain & \\
\hline 6 & body & $\mathrm{g}$ & $\mathrm{I} / \mathrm{E} \mathrm{SM}$ & $\mathrm{G}$ & 6.4 & plain & \\
\hline 7 & body & $\mathrm{g}$ & $\mathrm{I} / \mathrm{E} \mathrm{SM}$ & $\mathrm{B}$ & 6.8 & plain & \\
\hline 8 & body & $\mathrm{g}$ & I SM & $\mathrm{G}$ & 7.4 & overlapping brushed & \\
\hline 9 & body & $\mathrm{g} / \mathrm{b}$ & $\mathrm{I} / \mathrm{E} \mathrm{SM}$ & G & 9.2 & $2+$ rows fingernail punctates & \\
\hline 10 & body & $\mathrm{g}$ & $\mathrm{I} / \mathrm{E} \mathrm{SM}$ & $\mathrm{B}$ & 9.0 & fingernail punctates & \\
\hline 11 & body & $\mathrm{g} / \mathrm{b}$ & $\mathrm{I} / \mathrm{E} \mathrm{SM}$ & $\mathrm{G}$ & 7.2 & $2+$ rows fingernail punctates & \\
\hline 12 & body & $\mathrm{g} / \mathrm{b}$ & $\mathrm{I} / \mathrm{E} \mathrm{SM}$ & $\mathrm{B}$ & 7.2 & $\begin{array}{l}\text { straight incised lines and tool } \\
\text { punctated zone }\end{array}$ & \\
\hline 13 & body & $\mathrm{g}$ & $\mathrm{I} / \mathrm{E} \mathrm{SM}$ & $\mathrm{F}$ & 6.5 & $\begin{array}{l}\text { incised rectangles filled with tool } \\
\text { punctates }\end{array}$ & \\
\hline 14 & rim & $\mathrm{g} / \mathrm{b}$ & I SM & $\mathrm{B}$ & 5.9 & $\begin{array}{l}\text { diagonal incised lines and zoned } \\
\text { tool punctates }\end{array}$ & $\begin{array}{l}\mathrm{D}-\mathrm{RO}, \\
16.0 \mathrm{~cm} \text { OD }\end{array}$ \\
\hline 15 & rim & $\mathrm{g} / \mathrm{b}$ & $\mathrm{I} / \mathrm{E} \mathrm{SM}$ & $\mathrm{H}$ & 7.0 & $2+$ opposing incised lines & $\mathrm{D}-\mathrm{RO}$ \\
\hline 16 & body & g & I SM & G & 6.2 & cross-hatched incised lines & \\
\hline 17 & body & $\mathrm{g}$ & $\mathrm{I} / \mathrm{E} \mathrm{SM}$ & $\mathrm{A}$ & 5.8 & diagonal incised line & carinated bowl \\
\hline 18 & body & $\mathrm{g}$ & $\mathrm{I} / \mathrm{E} \mathrm{SM}$ & $\mathrm{B}$ & 8.8 & $3+$ straight incised lines & \\
\hline 19 & body & $\mathrm{g}$ & $\mathrm{I} / \mathrm{E} \mathrm{SM}$ & $\mathrm{F}$ & 8.4 & single incised line & carinated bowl \\
\hline 20 & body & $\mathrm{g}$ & I SM & $\mathrm{B}$ & 6.4 & pinched-fingernail & \\
\hline 21 & rim & $\mathrm{g}$ & $\mathrm{I} / \mathrm{E} \mathrm{SM}$ & A & 8.6 & plain & D-RO, thinned \\
\hline 22 & rim & $\mathrm{g}$ & $\mathrm{I} / \mathrm{E} \mathrm{SM}$ & $\mathrm{B}$ & 5.6 & engraved concentric semi-circles & $\mathrm{D}-\mathrm{RO}, 16.0 \mathrm{~cm}$ \\
\hline 23 & body & $\mathrm{g}$ & E B & B & 6.4 & engraved ladder & bottle \\
\hline
\end{tabular}

$\mathrm{ST}=$ surface treatment. $\mathrm{E}=$ exterior; $\mathrm{I}=$ interior, $\mathrm{SM}=$ smoothed; $\mathrm{B}=$ burnished; $\mathrm{FC}=$ firing conditions: $\mathrm{A}=$ fired and cooled in an oxidizing environment; $\mathrm{B}=$ fired and cooled in a reducing environment; $\mathrm{F}-\mathrm{H}=$ fired in a reducing environment and cooled in the open air; Th=thickness; Temper: $\mathrm{g}=$ grog; $\mathrm{b}=$ bone; $\mathrm{D}=\operatorname{direct}$ rim; $\mathrm{RO}=$ rounded lip; FL=flat lip; $\mathrm{OD}=$ orifice diameter

Fourteen of the sherds are from decorated portions of vessels, including carinated bowls and a bottle (see Table 1): brushed $(n=1)$, fingernail punctated $(n=2)$, incised-punctated $(n=3)$, incised $(n=5)$, pinched $(n=1)$, and engraved $(n=2)$. The presence of one brushed sherd and another sherd with engraved ladder elements suggests that there was a post-A.D. 1200 occupation at 41SM53 (see Table 1), but the principal Caddo occupation took place between ca. A.D. 900-1200 (see below). 
Also among the artifacts from 41SM53 are two arrow points. The first is $17.0 \mathrm{~mm}$ wide, $22.0 \mathrm{~mm}$ in length, $3.7 \mathrm{~mm}$ thick, and is made from red quartzite. The base is missing and the edges of the blade are serrated. The second arrow point is also made from red quartzite and is $21.4 \mathrm{~mm}$ in length, $13.6 \mathrm{~mm}$ wide, and $3.8 \mathrm{~mm}$ thick. The base is slightly expanding, suggesting it may be a Colbert point. Burial 1 at the site had a red quartzite tested cobble $(27.0 \mathrm{~mm}$ length, $16.0 \mathrm{~mm}$ width, and $9.0 \mathrm{~mm}$ thick). There is also one deer tooth included in the artifacts from the site but it lacks a specific provenience.

In addition, the Texas Archeological Research Laboratory at The University of Texas at Austin (TARL) has a collection of artifacts from 41SM53 that were donated by Sam Whiteside. These are primarily plain and decorated sherds from plain ware $(n=105)$, utility ware $(n=32)$, and fine ware $(n=10)$ vessels (Table 2$)$. About 88.4 percent of these sherds are from grog-tempered vessels and the remaining 11.6 percent of the sherds are from bone-tempered vessels. The decorated sherds in the TARL collection are indicative of a ca. A.D. 900-1200 Early Caddo occupation at the site.

Table 2. Ceramic sherds from 41SM53 in the TARL collections.

\begin{tabular}{lccc}
\hline Ware & Grog-tempered & Bone-tempered & $\mathrm{N}$ \\
\hline Plain & 94 & 11 & 105 \\
Utility & 28 & 4 & 32 \\
Fine & 8 & 2 & 10 \\
\hline Totals & 130 & 17 & 147 \\
\hline
\end{tabular}

Sherds from utility ware vessels comprise 76 percent of the decorated sherds from 41SM53 in the TARL collections (Table 3$)$. These are from vessels decorated with incised $(n=12,37.5$ percent of the utility wares), incised-punctated ( $\mathrm{n}=4,12.5$ percent), and punctated ( $\mathrm{n}=16,50$ percent) elements.

Table 3. Decorative elements in the decorated sherds from 41SM53 in the TARL collections.

\begin{tabular}{llll}
\hline Method/element & Rim & Body & N \\
\hline
\end{tabular}

Utility Ware

\section{Incised}

cross-hatched lines

curvilinear line

diagonal opposed lines

horizontal incised line or lines

parallel lines

straight line

$\begin{array}{lll}- & 1 & 1 \\ - & 1 & 1 \\ 1 & - & 1 \\ 4 & 1 & 5 \\ - & 3 & 3 \\ - & 1 & 1\end{array}$

\section{Incised-Punctated}

diagonal incised panels filled with tool punctates

straight incised line and adjacent zone

of tool punctates

\section{Punctated}

fingernail punctated rows

13

13

random tool punctates

$-$

3 
Table 3. Decorative elements in the decorated sherds from 41SM53 in the TARL collections, cont.

\begin{tabular}{llll}
\hline Method/element & Rim & Body & N \\
\hline Fine Ware & & & \\
$\begin{array}{l}\text { Engraved } \\
\quad \text { curvilinear lines and excised semi-circle } \\
\text { diagonal opposed lines }\end{array}$ & - & 1 & 1 \\
$\quad \begin{array}{l}\text { diagonal opposed lines and large nested } \\
\quad \text { excised triangle element, CB }\end{array}$ & - & 1 & 1 \\
$\quad \begin{array}{l}\text { multiple curvilinear lines, Bt } \\
\text { multiple curvilinear lines with hatched }\end{array}$ & - & - & 3 \\
$\quad \begin{array}{l}\text { zones, Bt } \\
\text { parallel lines }\end{array}$ & - & 1 & 1 \\
$\begin{array}{l}\text { Engraved-Excised Punctated } \\
\quad \text { vertical engraved lines with excised }\end{array}$ & 1 & 2 & 2 \\
$\quad$ punctates between several lines & & & 1 \\
\hline Totals & 9 & 33 & 42 \\
\hline
\end{tabular}

$\mathrm{Bt}=$ bottle; $\mathrm{CB}=$ carinated bowl

The incised sherds are from Davis Incised and Dunkin Incised vessels (see Suhm and Jelks 1962) with multiple horizontal incised lines and diagonal opposed incised lines (Figure 2b). Two rims are from Pennington Punctated-Incised vessels with diagonal incised panels filled with tool punctates (Figure 2a). The punctated body sherds, both fingernail and tool punctated, are likely from Kiam Incised and Weches Fingernail Impressed jars.

Six of the engraved sherds are from bowls or carinated bowls. One rim from a probable Spiro Engraved vessel has a series of vertical engraved lines, and between two of the vertical lines are small excised punctations (see Figure 2c). Three other sherds are from Holly Fine Engraved vessels (see Figure 2d-e). One has multiple curvilinear lines around an excised semi-circle (see Suhm and Jelks 1962:Plate 39f, h), while two others have a series of diagonal opposed engraved lines. One Holly Fine Engraved carinated bone rim (see Figure 2e) has finely drawn diagonal opposed lines and a large nested excised triangle between the diagonal opposed lines (see Suhm and Jelks 1962:Plate 39a-b, e).

Four of the engraved sherds in the TARL collection from 41SM53 are from bottles. Three have multiple curvilinear lines, and may be from Holly Fine Engraved and Spiro Engraved vessels, and the fourth bottle sherd (probably from a Spiro Engraved bottle) has multiple curvilinear lines and hatched zones (see Figure 2f).

In addition to the ceramic vessel sherds, there are two unburned deer bones in the collection from 41SM53, two pieces of burned clay, as well as 24 pieces of lithic debris. The lithic debris includes a noncortical flake of non-local gray chert, a non-cortical piece of quartz, and 22 pieces of lithic debris on local raw materials: quartzite $(n=4,100$ percent cortical), red chert $(n=4,100$ percent cortical), brown chert $(n=4$, 100 percent cortical), and petrified wood ( $\mathrm{n}=10,90$ percent cortical). The cortical surfaces are smoothed and stream-rolled, indicating raw materials for knapping was gathered from local stream gravels. 


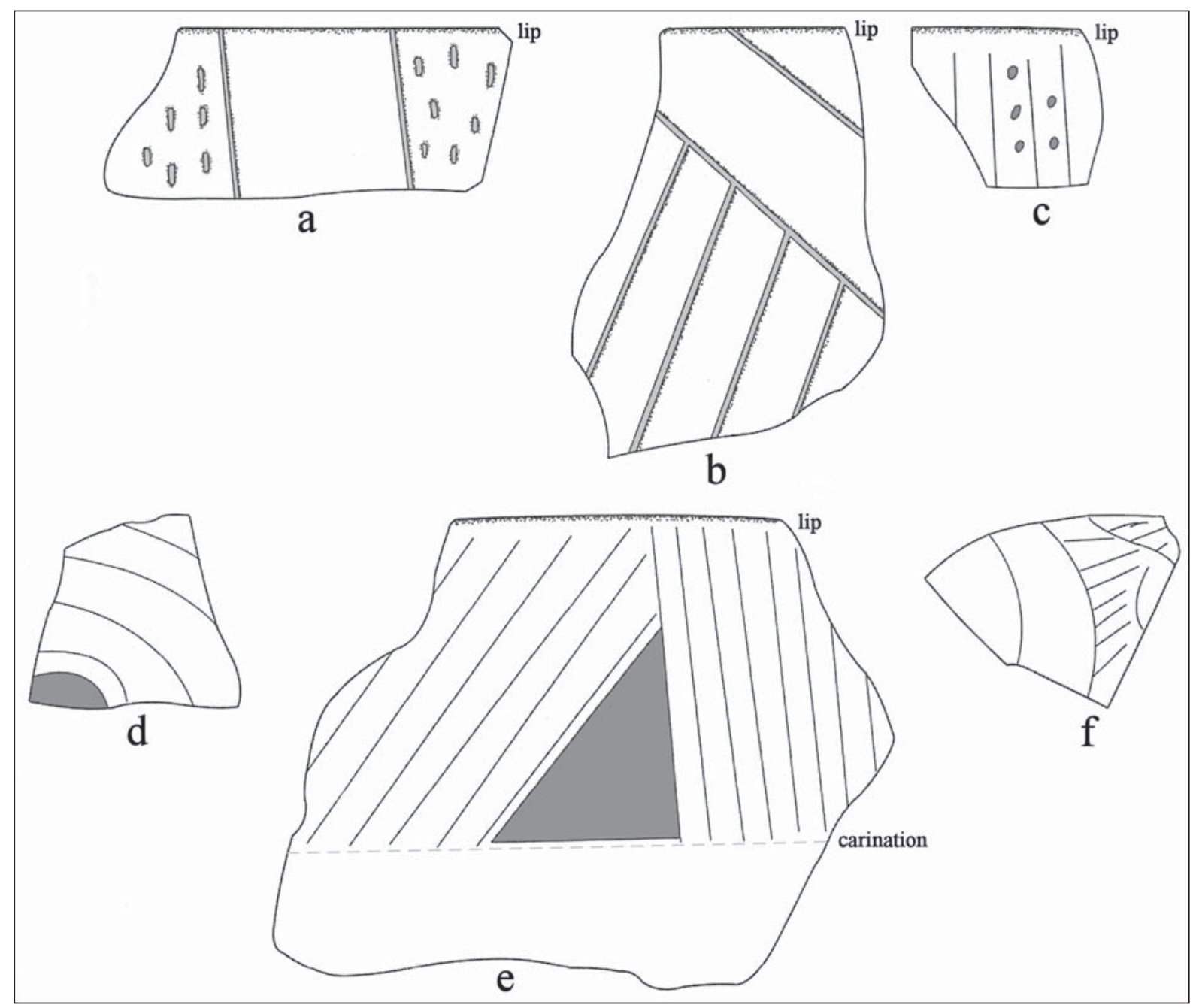

Figure 2. Decorative elements on selected sherds from 41SM53: a, Pennington Punctated-Incised rim; b, Dunkin Incised rim; c, f, possible Spiro Engraved rim and body sherds; d-e, Holly Fine Engraved rim and body sherds.

\section{SM57, The Emma Sanford Site (P-1)}

The Emma Sanford site is located on an alluvial landform on the north side of Prairie Creek. Mr. Whiteside identified a $9 \times 9 \mathrm{~m}$ midden area in his investigations (see Figure 3). In this midden area he also identified two ash features; one was circular and $1.2 \mathrm{~m}$ in diameter; the second one was oval-shaped and 1.8 $\mathrm{x} 2.7 \mathrm{~m}$ in size (Figure 3). There were also two circular pits that were $0.8 \mathrm{~m}$ in diameter, though his drawings of both of them are not to scale. He also plotted 12 post holes in the central and western parts of the midden that were each ca. $20 \mathrm{~cm}$ in diameter. These post holes formed no clear spatial patterning, although it is speculated that parts of two straight walls to a rectangular structure are present; in any event, the post holes are evidence that a Caddo structure was present at the Emma Sanford site.

There are 14 rim sherds from the Emma Sanford site in the Whiteside collection. Five are from plain grog or grog-bone-tempered vessels (Table 4), and the others are from decorated vessels. Ten of the rim sherds ( 71 percent) are from grog-tempered vessels, three ( 21 percent) also have bone temper inclusions, and one rim is tempered with grog and hematite ( 7 percent). 


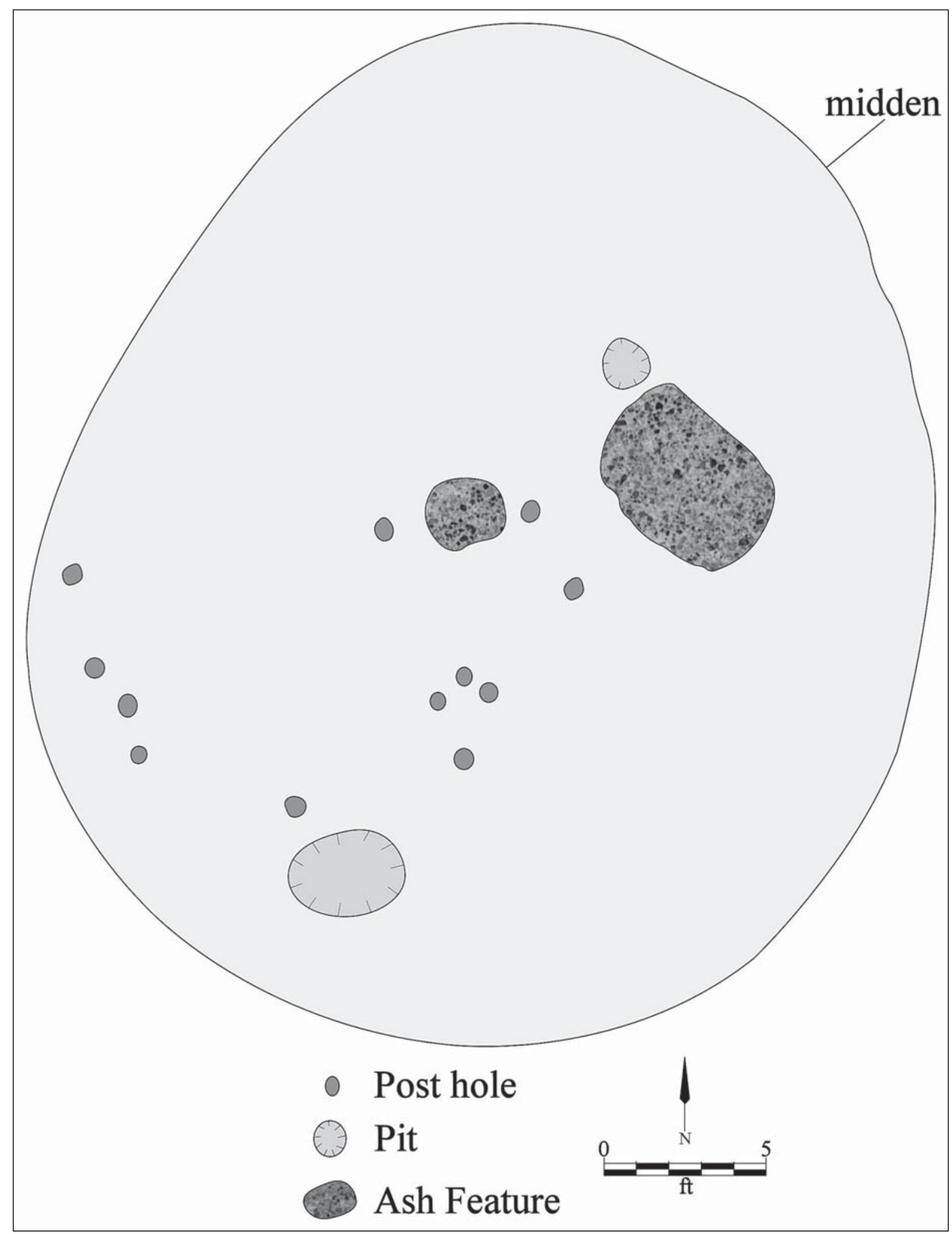

Figure 3. Excavations at the Emma Sanford site (41SM57) by Sam Whiteside. 
Table 4. Sherds from the Emma Sanford site (41SM57).

\begin{tabular}{|c|c|c|c|c|c|c|}
\hline$\#$ & Temper & $\mathrm{ST}^{*}$ & $\mathrm{FC}$ & $\begin{array}{l}\text { Th } \\
(\mathrm{mm})\end{array}$ & Decoration & Comments \\
\hline 1 & $\mathrm{~g}$ & $\mathrm{I} / \mathrm{E} \mathrm{SM}$ & B & 7.3 & opposing incised lines & D-RO, thinned \\
\hline 2 & $\mathrm{~g}$ & E SM & B & 9.3 & cross-hatched incised lines & $\mathrm{D}-\mathrm{FL}$ \\
\hline 3 & g & $\mathrm{I} / \mathrm{E} \mathrm{SM}$ & B & 7.3 & horizontal rows tool punctates & D-RO, ext f. \\
\hline 4 & $\mathrm{~g} / \mathrm{h}$ & $\mathrm{I} / \mathrm{E} \mathrm{SM}$ & B & 7.8 & 2 rows horizontal tool punctates & D-RO, ext. f. \\
\hline 5 & g & $\mathrm{I} / \mathrm{E} \mathrm{SM}$ & $\mathrm{F}$ & 7.2 & $2+$ rows tool punctates & D-RO, ext. f. \\
\hline 6 & $\mathrm{~g} / \mathrm{b}$ & E SM & $\mathrm{F}$ & 6.5 & $\begin{array}{l}\text { diagonal incised line and tool } \\
\text { punctated-filled zone }\end{array}$ & D-FL \\
\hline 7 & $\mathrm{~g}$ & $\mathrm{I} / \mathrm{E} \mathrm{SM}$ & B & 7.9 & $\begin{array}{l}\text { horizontal incised line and tool } \\
\text { punctated zone }\end{array}$ & D-RO, ext. f. \\
\hline 8 & $\mathrm{~g} / \mathrm{b}$ & $\mathrm{I} / \mathrm{E} \mathrm{SM}$ & A & 5.7 & $\begin{array}{l}\text { diagonal incised line and tool } \\
\text { punctated zone }\end{array}$ & $\mathrm{D}-\mathrm{RO}$ \\
\hline 9 & g & E SM & G & 6.7 & $\begin{array}{l}2+\text { curvilinear incised lines and } \\
\text { tool punctated zone }\end{array}$ & $\mathrm{D}-\mathrm{RO}$, thinned interior \\
\hline 10 & $\mathrm{~g}$ & $\mathrm{I} / \mathrm{E} \mathrm{SM}$ & B & 7.3 & plain & D-RO \\
\hline 11 & $\mathrm{~g}$ & E SM & B & 7.0 & plain & $\mathrm{EV}-\mathrm{RO}$, thinned interior \\
\hline 12 & $\mathrm{~g} / \mathrm{b}$ & $\mathrm{I} / \mathrm{E} \mathrm{SM}$ & $\mathrm{F}$ & 7.0 & plain & D-RO \\
\hline 13 & $\mathrm{~g}$ & $\mathrm{I} / \mathrm{E} \mathrm{SM}$ & A & 5.7 & plain & D-RO, ext. f \\
\hline 14 & $\mathrm{~g}$ & $\mathrm{I} / \mathrm{E} \mathrm{SM}$ & G & 6.6 & plain & D-RO, ext. f \\
\hline
\end{tabular}

$\mathrm{ST}=$ surface treatment. $\mathrm{E}=$ exterior; $\mathrm{I}=$ interior, $\mathrm{SM}=$ smoothed; $\mathrm{B}=$ burnished; $\mathrm{FC}=$ firing conditions: $\mathrm{A}=$ fired and cooled in an oxidizing environment; $\mathrm{B}=$ fired and cooled in a reducing environment; $\mathrm{F}-\mathrm{H}=$ fired in a reducing environment and cooled in the open air; $\mathrm{Th}=$ thickness; Temper: $\mathrm{g}=$ grog; $\mathrm{h}=$ hematite; $\mathrm{b}=$ bone; $\mathrm{D}=$ direct rim; $\mathrm{EV}=$ everted rim; $\mathrm{RO}=$ rounded lip; $\mathrm{FL}=$ flat lip; ext f.=exterior folded lip

One sherd has opposing incised lines and one has cross-hatched incised lines. Three rims have horizontal rows of tool punctates, and four rims have horizontal or diagonal incisd lines and zones of tool punctates. Sherd 9 has curvilinear incised lines and zones of tool punctates (see Table 4); the decorative elements compare favorably with Crockett Curvilinear Incised (Suhm and Jelks 1962). It also has charred residue on the interior surface. The absence of brushed sherds suggests that the Emma Sanford site was likely occupied by Caddo peoples before ca. A.D. 1200.

There is also a large collection of sherds $(\mathrm{n}=957)$ from Caddo ceramic vessels at TARL from the Emma Sanford site. This includes the following:

- 2 plain rim sherds (grog-tempered);

- 902 plain body sherds (833 tempered with grog and 69 tempered with bone); and

- 51 base sherds (44 tempered with grog and 7 tempered with bone).

Approximately 92 percent of the plain rim, body, and base sherds are from grog-tempered vessels, and the remainder ( 8 percent) are from bone-tempered vessels.

Two miscellaneous decorated sherds were found mixed with the plain sherds in the TARL collection. One is a grog-tempered body sherd with parallel incised lines and the other is a grog-tempered exterior red-slipped body sherd (Sanders Plain). 


\section{SM152, Mary Laura (Chapman) Davis Site (P-6)}

Work was done here in the 1950s-1960s. The collection has 13 rim or body sherds (Table 5) as well as a heat-treated piece of quartzite lithic debris (\#4), a grayish-white chert core fragment (\#5), and a quartzite chunk/fire-cracked rock (\#6).

Table 5. Sherds from the Mary Laura (Chapman) Davis Site (41SM152).

\begin{tabular}{|c|c|c|c|c|c|c|c|}
\hline \# & $\begin{array}{l}\text { Sherd } \\
\text { type }\end{array}$ & Temper & $\mathrm{ST}^{*}$ & $\mathrm{FC}$ & $\begin{array}{l}\text { Th } \\
(\mathrm{mm})\end{array}$ & Decoration & Comments \\
\hline 1 & rim & $\mathrm{g} / \mathrm{b}$ & $\mathrm{I} / \mathrm{E} \mathrm{SM}$ & G & 8.3 & diagonal incised lines, & $22 \mathrm{~cm}$ OD, D-RO \\
\hline 2 & body & $\mathrm{g}$ & I SM & G & 8.3 & plain & \\
\hline 3 & body & $\mathrm{b} / \mathrm{h}$ & I SM & G & 10.7 & zone tool punctated & \\
\hline 7 & base & $\mathrm{g} / \mathrm{b}$ & I SM & G & 9.6 & plain & \\
\hline 8 & body & $\mathrm{g}$ & - & G & 7.0 & plain & \\
\hline 9 & body & $\mathrm{g}$ & I SM & G & 6.6 & parallel incised lines & \\
\hline 10 & body & g & - & $\mathrm{B}$ & 6.2 & plain & carinated bowl \\
\hline 11 & rim & $\mathrm{g}$ & - & G & 6.0 & diagonal pinched ridges & $\mathrm{D}-\mathrm{RO}$ \\
\hline 12 & body & $\mathrm{g} / \mathrm{SP}$ & EB & $\mathrm{B}$ & 5.8 & $\begin{array}{l}\text { parallel engraved lines, } \\
8+\end{array}$ & \\
\hline 13 & body & g & $\mathrm{I} / \mathrm{E} \mathrm{SM}$ & $\mathrm{B}$ & 5.3 & plain & \\
\hline 14 & body & $\mathrm{g} / \mathrm{SP}$ & I SM & $\mathrm{B}$ & 5.4 & $\begin{array}{l}\text { closely-spaced parallel } \\
\text { incised lines }\end{array}$ & \\
\hline 15 & body & $\mathrm{g} / \mathrm{SP}$ & E B & $\mathrm{B}$ & 6.5 & plain & \\
\hline 16 & body & g & $\mathrm{I} / \mathrm{E} \mathrm{SM}$ & G & 6.3 & plain & \\
\hline
\end{tabular}

$\mathrm{ST}=$ surface treatment. $\mathrm{E}=$ exterior; $\mathrm{I}=$ interior, $\mathrm{SM}=$ smoothed; $\mathrm{B}=$ burnished; $\mathrm{FC}=$ firing conditions: $\mathrm{A}=$ fired and cooled in an oxidizing environment; $\mathrm{B}=$ fired and cooled in a reducing environment; $\mathrm{F}-\mathrm{H}=$ fired in a reducing environment and cooled in the open air; Th=thickness; Temper: $\mathrm{g}=$ grog; $\mathrm{h}=$ hematite; $\mathrm{b}=$ bone; $\mathrm{SP}=$ sandy paste; $\mathrm{D}=$ direct rim; $\mathrm{RO}=$ rounded lip; $\mathrm{OD}=$ orifice diameter

The 13 sherds are from vessels tempered with grog $(\mathrm{n}=10)$, grog-bone $(\mathrm{n}=2)$, and bone-hematite $(\mathrm{n}=1)$. Three of the grog-tempered sherds have a sandy clay paste (see Table 5). The six decorated sherds in the small assemblage have parallel and diagonal incised lines $(n=3)$, a zoned incised-punctated body sherd closely-spaced parallel engraved lines $(n=1)$, and pinched ridges $(n=1)$. There are no brushed sherds in the assemblage from the site, again suggesting a Caddo occupation that predated ca. A.D. 1200.

\section{SM153, Will Butler Site (P-7)}

The Whiteside collection has 10 rim or body sherds from the Will Butler site (Table 6). These are from grog-tempered $(n=8)$, grog-hematite $(n=1)$, and bone-grog-tempered $(n=1)$ vessels. These sherds are from vessels fired predominantly in a reducing environment.

Table 6. Sherds from the Will Butler site (41SM153).

\begin{tabular}{|c|c|c|c|c|c|c|c|}
\hline \# & $\begin{array}{l}\text { Sherd } \\
\text { type }\end{array}$ & Temper & $\mathrm{ST}^{*}$ & $\mathrm{FC}$ & $\begin{array}{l}\text { Th } \\
(\mathrm{mm})\end{array}$ & Decoration & Comments \\
\hline 1 & body & $\mathrm{g}$ & - & $\mathrm{F}$ & $8.4-9.6$ & horizontal incised line on body & bowl? \\
\hline 2 & rim & $\mathrm{g} / \mathrm{h}$ & - & F & 7.5 & plain & D-RO \\
\hline 3 & rim & $\mathrm{b} / \mathrm{g}$ & $\mathrm{I} / \mathrm{E} \mathrm{SM}$ & $\mathrm{G}$ & 8.5 & plain & D-FL \\
\hline
\end{tabular}


Table 6. Sherds from the Will Butler site (41SM153), cont.

\begin{tabular}{|c|c|c|c|c|c|c|c|}
\hline \# & $\begin{array}{l}\text { Sherd } \\
\text { type }\end{array}$ & Tempe & er $\mathrm{ST}^{*}$ & $\mathrm{FC}$ & $\begin{array}{l}\text { Th } \\
(\mathrm{mm})\end{array}$ & Decoration & Comments \\
\hline 4 & body & $\mathrm{g}$ & I/E SM & B & 7.1 & single straight engraved line & \\
\hline 5 & rim & $\mathrm{g}$ & I SM & $\mathrm{B}$ & 8.4 & cross-hatched incised lines & D-RO, ext. f. \\
\hline 6 & body & $\mathrm{g}$ & $\mathrm{B} / \mathrm{I} \mathrm{SM}$ & $\mathrm{B}$ & 6.3 & $\begin{array}{l}\text { engraved parallel and opposed } \\
\text { lines }\end{array}$ & \\
\hline 7 & body & $\mathrm{g}$ & I SM & B & 9.6 & $\begin{array}{l}\text { diagonal incised lines and zone filled } \\
\text { with linear punctates on rim; rows } \\
\text { of tool punctates on body }\end{array}$ & \\
\hline 8 & rim & $\mathrm{g}$ & I SM & A & 12.5 & diagonal incised lines & $\mathrm{D}-\mathrm{RO}$ \\
\hline 9 & rim & $\mathrm{g}$ & I SM & G & 6.4 & $\begin{array}{l}\text { diagonal or cross-hatched lines } \\
\text { and zones of tool punctates }\end{array}$ & $-\mathrm{RO}$ \\
\hline 10 & rim & $\mathrm{g}$ & I SM & $\mathrm{F}$ & 6.9 & $\begin{array}{l}\text { diagonal incised lines and zones } \\
\text { tool punctates }\end{array}$ & $\mathrm{D}-\mathrm{RO}$ \\
\hline
\end{tabular}

$\mathrm{ST}=$ surface treatment. $\mathrm{E}=$ =xterior; $\mathrm{I}=$ interior, $\mathrm{SM}=$ smoothed; $\mathrm{B}=$ burnished; $\mathrm{FC}=$ firing conditions: $\mathrm{A}=$ fired and cooled in an oxidizing environment; $\mathrm{B}=$ fired and cooled in a reducing environment; $\mathrm{F}-\mathrm{H}=\mathrm{fired}$ in a reducing environment and cooled in the open air; Th=thickness; Temper: $\mathrm{g}=$ grog; $\mathrm{D}=$ direct rim; $\mathrm{RO}=$ rounded lip; $\mathrm{FL}=-$ flat lip; ext f.=exterior folded lip.

The decorated sherds from the site have horizontal, diagonal, and cross-hatched incised elements $(\mathrm{n}=3)$, zoned incised-punctated elements $(n=3)$, and engraved sherds with straight, parallel, or opposed lines.

\section{Edna Smith Site (41SM154)}

This site was named the Edna Smith site $(\mathrm{P}-8)$ in Mr. Whiteside's journal. There are five sherds from this site (Table 7). They are from vessels tempered with grog $(n=2)$, grog-hematite $(n=1)$, grog-organics $(\mathrm{n}=1)$, and grog-bone-hematite. Four of the five sherds are from vessels fired in a reducing environment, and the other is from a vessel that was fired and cooled in an oxidizing or high oxygen environment.

Table 7. Sherds from the Edna Smith site (41SM154).

\begin{tabular}{|c|c|c|c|c|c|c|c|}
\hline \# & Sherd & Temper & $\mathrm{ST}^{*}$ & FC & $\mathrm{Th}$ & $\begin{array}{l}\text { Decoration } \\
(\mathrm{mm})\end{array}$ & Comments \\
\hline 1 & Rim & $\mathrm{g} / \mathrm{h}$ & E SM & G & 6.1 & plain & $\begin{array}{l}\text { D-RO, bottle } \\
\text { neck }\end{array}$ \\
\hline 2 & Rim & g/org & I SM & A & 8.8 & row tool punctates & $\mathrm{D}-\mathrm{FL}$ \\
\hline 3 & Rim & $\mathrm{g} / \mathrm{b} / \mathrm{h}$ & E SM & $\mathrm{F}$ & 6.4 & plain & $\begin{array}{l}\text { D-RO, int. } \\
\text { thinned }\end{array}$ \\
\hline 4 & Body & $\mathrm{g}$ & I SM & $\mathrm{B}$ & 7.0 & opposing incised lines & - \\
\hline 5 & Body & $\mathrm{g}$ & I SM & $\mathrm{F}$ & 9.3 & rows of tool punctates & Carinated bowl \\
\hline
\end{tabular}

$\mathrm{ST}=$ surface treatment. $\mathrm{E}=$ exterior; $\mathrm{I}=$ interior, $\mathrm{SM}=$ smoothed; $\mathrm{FC}=$ firing conditions: $\mathrm{A}=$ fired and cooled in an oxidizing environment; $\mathrm{B}=$ fired and cooled in a reducing environment; $\mathrm{F}-\mathrm{G}=$ fired in a reducing environment and cooled in the open air; Temper: $\mathrm{g}=$ grog; $\mathrm{h}=$ hematite; $\mathrm{b}=$ bone; org=organics; $\mathrm{D}=$ direct rim; $\mathrm{RO}=$ rounded lip; FL=flat lip

Sherd 1 is a plain, straight bottle neck, $6.1 \mathrm{~cm}$ in length, and with an orifice diameter of $3.7 \mathrm{~cm}$. Sherd 2 is from a vessel with an orifice diameter of $18.0 \mathrm{~cm}$, probably a jar, and it has a row of tool punctates on the rim. Sherd 3 is a plain rim, and Sherd 4 is a body sherd with opposed incised lines. Sherd 5 is from a 
carinated bowl that had U-shaped punctates on one side of the carination point and tear-shaped punctates on the other side (see Table 7).

\section{$41 S M 156(P-2 A)$}

There are 49 rim, body, or base sherds from 41SM156 in the Whiteside collection, along with a bowl sherd from a long-stemmed and grog-tempered Red River style pipe (Table 8). The sherds are from vessels tempered with grog $(n=40,81.6$ percent); grog with a sandy paste $(n=3,6.1$ percent); grog-bone $(n=5,10.2$ percent), and bone ( $\mathrm{n}=1,2.0$ percent). The majority of the sherds are also from vessels that were fired in a reducing environment $(n=45)$; only 6 percent $(n=3)$ were from vessels fired in an oxidizing environment.

Table 8. Sherds from 41SM156.

\begin{tabular}{|c|c|c|c|c|c|c|c|}
\hline$\#$ & Sherd & Temper & $\mathrm{ST}^{*}$ & $\mathrm{FC}$ & $\mathrm{Th}$ & $\begin{array}{l}\text { Decoration } \\
(\mathrm{mm})\end{array}$ & Comments \\
\hline 1 & base & $\mathrm{g} / \mathrm{SP}$ & E SM & $\mathrm{G}$ & 9.3 & plain & \\
\hline 2 & body & g & E SM & G & 6.1 & plain & \\
\hline 3 & body & g & - & B & 6.2 & plain & \\
\hline 4 & body & g & I/E SM & F & 8.1 & plain & \\
\hline 5 & base & $\mathrm{g}$ & E SM & F & 10.6 & plain & \\
\hline 6 & body & $\mathrm{g}$ & E SM & A & 7.7 & plain & \\
\hline 7 & body & g & I/E SM & G & 7.0 & plain & \\
\hline 8 & base & $\mathrm{g} / \mathrm{b}$ & I/E SM & G & 11.7 & plain & \\
\hline 9 & base & $\mathrm{g} / \mathrm{b}$ & E SM & $\mathrm{F}$ & 8.8 & plain & $\begin{array}{l}\text { spindle whorl }(4.0 \mathrm{~mm} \\
\text { diameter drilled hole })\end{array}$ \\
\hline 10 & body & g & E SM & B & 5.2 & plain & \\
\hline 11 & body & $\mathrm{g}$ & - & A & 7.6 & plain & \\
\hline 12 & body & $\mathrm{g}$ & E/I SM & F & 6.9 & plain & \\
\hline 13 & body & $\mathrm{g}$ & I/E SM & F & 7.9 & plain & \\
\hline 14 & body & g & E SM & F & 7.7 & plain & \\
\hline 15 & body & g & E SM & G & 8.9 & plain & \\
\hline 16 & body & $\mathrm{g}$ & I/E SM & F & 7.0 & plain & \\
\hline 17 & body & $\mathrm{g}$ & E SM & $\mathrm{F}$ & 8.0 & plain & \\
\hline 18 & base & $\mathrm{g}$ & - & G & 10.2 & plain & \\
\hline 19 & body & g & I/E SM & F & 7.2 & plain & \\
\hline 20 & body & $\mathrm{g}$ & E SM & $\mathrm{F}$ & 7.4 & plain & \\
\hline 21 & body & $\mathrm{g}$ & - & G & 10.4 & parallel brushed & \\
\hline 22 & body & $\mathrm{g}$ & E SM & $\mathrm{H}$ & 7.6 & plain & \\
\hline 23 & body & $\mathrm{g}$ & E SM & $\mathrm{F}$ & 8.2 & plain & \\
\hline 24 & body & $\mathrm{g} / \mathrm{SP}$ & E SM & B & 7.9 & plain & \\
\hline 25 & body & $\mathrm{g}$ & E SM & $\mathrm{F}$ & 9.0 & plain & \\
\hline 26 & body & $\mathrm{g} / \mathrm{b}$ & - & B & 8.5 & str. incised line & \\
\hline 27 & body & $\mathrm{g}$ & I/E SM & $\mathrm{F}$ & 7.4 & plain & \\
\hline 28 & base & $\mathrm{g}$ & E SM & $\mathrm{G}$ & 10.0 & plain & \\
\hline 29 & rim-pipe & $g$ & E B & G & 4.0 & plain & $\begin{array}{l}\text { Red River style, pipe bowl } \\
4.0 \mathrm{~cm} \text { OD }\end{array}$ \\
\hline 30 & body & $\mathrm{g}$ & E SM & B & 5.4 & plain & \\
\hline 31 & base & $\mathrm{g}$ & E SM & G & 10.4 & plain & \\
\hline
\end{tabular}


Table 8. Sherds from 41SM156, cont.

\begin{tabular}{|c|c|c|c|c|c|c|c|}
\hline \# & Sherd & Temper & $\mathrm{ST}^{*}$ & $\mathrm{FC}$ & $\mathrm{Th}$ & $\begin{array}{l}\text { Decoration } \\
(\mathrm{mm})\end{array}$ & Comments \\
\hline 32 & base & $\mathrm{g}$ & & - & B & 10.3 & plain \\
\hline 33 & body & g & & - & B & N/A & plain \\
\hline 34 & body & g & & I/E SM & $\mathrm{H}$ & 4.3 & plain \\
\hline 35 & body & $\mathrm{g}$ & & - & - & N/A & plain \\
\hline 36 & base & $\mathrm{g}$ & & E SM & G & 10.9 & plain \\
\hline 37 & body & $\mathrm{g} / \mathrm{b}$ & & I/E SM & B & 8.2 & plain \\
\hline 38 & body-ba & se $g$ & & - & G & 10.7 & $\begin{array}{l}\text { punctated rows } \\
\text { at lower body }\end{array}$ \\
\hline 39 & body & $\mathrm{g}$ & & E B & $\mathrm{F}$ & 7.6 & $\begin{array}{l}\text { closely-spaced } \\
\text { engraved } \\
\text { curvilinear (cf. Holly) }\end{array}$ \\
\hline 40 & body & g & & I SM & G & 8.2 & horizontal incised lines \\
\hline 41 & rim & g & & $\mathrm{I} / \mathrm{E} \mathrm{B}$ & G & 7.7 & $\begin{array}{l}\text { D-Ext f, opposing } \\
\text { engraved lines (cf. Holly) }\end{array}$ \\
\hline 42 & rim & $\mathrm{g}$ & & I SM & B & 6.0 & $2+$ rows tool punctates \\
\hline 43 & body & $\mathrm{g}$ & & I SM & G & 7.3 & tool punctated rows \\
\hline 44 & body & $\mathrm{g}$ & & I SM & G & 8.5 & $\begin{array}{l}\text { fingernail punctated } \\
\text { rows }(3+)\end{array}$ \\
\hline 45 & body & $\mathrm{g}$ & & I/E SM & $\mathrm{H}$ & 6.6 & UID engraved element \\
\hline 46 & body & g & & I SM & B & 6.3 & $\begin{array}{l}\text { str. incised line and } \\
\text { row of tool punctates }\end{array}$ \\
\hline 47 & rim & $\mathrm{b}$ & & - & $\mathrm{F}$ & 6.6 & random tool punctates \\
\hline 48 & body & $\mathrm{g}$ & & E B & G & 7.3 & $\begin{array}{l}\text { closely-spaced straight } \\
\text { engraved lines }\end{array}$ \\
\hline 49 & body & $\mathrm{g} / \mathrm{SP}$ & & - & $\mathrm{F}$ & 5.7 & $\begin{array}{l}\text { appliqued fillet and } \\
\text { opposed incised } \\
\text { lines (cf. Pease Brushed } \\
\text { Incised) }\end{array}$ \\
\hline 50 & rim & $\mathrm{g} / \mathrm{b}$ & & - & A & 8.6 & $\begin{array}{l}\text { incised triangle } \\
\text { filled with small } \\
\text { tool punctates; D-FL }\end{array}$ \\
\hline
\end{tabular}

$\mathrm{ST}=$ surface treatment. $\mathrm{E}=$ exterior; $\mathrm{I}=$ interior, $\mathrm{SM}=$ smoothed; $\mathrm{FC}=$ firing conditions: $\mathrm{A}=$ fired and cooled in an oxidizing environment; $\mathrm{B}=$ fired and cooled in a reducing environment; $\mathrm{F}-\mathrm{G}=$ fired in a reducing environment and cooled in the open air; Temper: $\mathrm{g}=\mathrm{grog}$; $\mathrm{b}=$ bone; $\mathrm{SP}=$ sandy paste; $\mathrm{D}=$ direct rim; $\mathrm{RO}=$ rounded lip; $\mathrm{FL}=$ flat lip; Ext $\mathrm{f}=$ exterior folded lip

The 15 decorated sherds (see Table 8 ) are from both utility ware and fine ware vessels. The utility ware sherds have brushed $(n=1)$, incised $(n=2)$, punctated $(n=5)$, incised-punctated $(n=2)$, and incised-appliqued $(n=1)$ decorative elements; the latter may be from a Pease Brushed-Incised jar. The fine ware sherds $(n=4)$ have engraved decorative elements, including two sherds that compare favorably to Holly Fine Engraved (see Suhm and Jelks 1962). If the decorated sherds are from a single component Caddo occupation, the occurrence of a brushed body sherd, an incised-appliqued Pease Brushed-Incised sherd, and two possible Holly Fine Engraved sherds suggests that 41SM156 was occupied early in the Middle Caddo period, between ca. A.D. $1200-1300$. 
There are two lithic artifacts in the collection from the site. They include a light gray chert non-cortical flake tool (\#51) with a unilateral use-worn area, and a gray chert non-cortical piece of lithic debris (\#52).

\section{SUMMARY AND CONCLUSIONS}

Although 60 some-odd years have passed since Sam Whiteside conducted archaeological investigations on Prairie Creek in eastern Smith County, Texas, it is remarkable that the artifacts and notes he collected are still available for study. Much of this is a tribute to the Texas Archeological Research Laboratory in Austin, Texas, for the role it plays in preserving artifacts for future study. Credit should also go to the Whiteside family for keeping up with and making available Mr. Whiteside's' contributions to Texas archaeology. Information gleaned from his investigations at these six sites on Prairie Creek should add important information regarding the development of the Caddo culture in this area.

Four of the six sites reported herein, from the artifacts presented, would appear to date to the Early Caddo time period (A.D. 900-1200). This is based primarily on no sherds with brushing decorative elements and what we think are early Caddo ceramic decorative elements (i.e., Holly Fine Engraved). The other two sites, the Edna Smith site (41SM154) and 41SM156, have limited amounts of sherds with brushing, which could indicate a slightly later time period during which they were occupied, ca. A.D. 1200-1300. What is interesting is that none of the six sites reported in this article, nor any other Caddo sites in this part of Smith County, Texas, appear to date later than A.D. 1450. The reasons for this are still unclear. Hopefully this brief article will add a grain of information to this and other questions regarding the Caddo archaeological record in the Sabine River basin of East Texas that need answers.

\section{ACKNOWLEDGMENTS}

The senior author would like to give special thanks to Tim Perttula, junior author, for his time spent at TARL doing research on these sites, and for his invaluable assistance in helping put this article together.

\section{REFERENCES CITED}

Suhm, D. A. and E. B. Jelks (editors)

1962 Handbook of Texas Archeology: Type Descriptions. Special Publication No. 1, Texas Archeological Society, and Bulletin No. 4, Texas Memorial Museum, Austin. Reprinted in 2009, Gustav's Library, Davenport, Iowa.

Walters, M.

2005 A Profile in East Texas Archeology. Bulletin of the Texas Archeological Society 75:119-121.

2009 The Henry Chapman Site (41SM56). Journal of Northeast Texas Archaeology 31:11-35. 